\title{
Linkage between perceived corporate social responsibility and employee engagement: Mediation effect of organizational identification
}

\author{
Osveh Esmaeelinezhad (Corresponding author) \\ Department of Administrative Studies and Politics, Faculty of Economics and Administration \\ University of Malaya, 50603 Kuala Lumpur, MALAYSIA \\ Tel: (+98) $9123094670 \quad$ E-mail: osveh.1360@gmail.com
}

Dr. Kuppusamy Singaravelloo

Tel: (+60) 122371992 Email: kuppusamy_s@um.edu.my

Dr. Ali Boerhannoeddin

Tel: (+60) 126345857 Email: Dr. Ali aliboer@um.edu.my

Doi:10.5296/ijhrs.v5i3.8376 URL: http://dx.doi.org/10.5296/ijhrs.v5i3.8376

\begin{abstract}
This study employs structural equation modelling technique to examine the direct effect of perceived external corporate social responsibility and perceived internal corporate social responsibility on employee engagement as well as the mediated link through organizational identification. Social exchange theory and social identity theory used to explain the relationships between the variables in this study. It was conducted among 1080 employees of four selected organizations in Iran which are among the main pioneers in performing corporate social activities. The test of research model shows the positive effect of perceived external corporate social responsibility and perceived internal corporate social responsibility on employee engagement. In addition, it confirms that organizational identification has a mediating role in above relationships. The results have also contributed to a better understanding of corporate social responsibility in Iran as a developing country in which corporate social responsibility has recently gained attention and thus there is still a lack of understanding about it. The findings would be useful for managers to have a better insight towards applying corporate social responsibility in line with increasing employees' identification and engagement.
\end{abstract}

Keywords: Perceived external corporate social responsibility, Perceived Internal corporate 
social responsibility, Corporate social responsibility (CSR), Employee engagement, Organizational identification, Structural equation modelling (SEM). Partial least squares (PLS)

\section{Introduction}

Corporate social responsibility (CSR) has gained the interest of business organizations since 1980s (Shen \& Jiuhua Zhu, 2011). The present research adopts the social perspective, describing CSR based on the company's efforts and position associated with its perceived societal as well as stakeholder responsibilities (Brown \& Dacin, 1997; Sen \& Bhattacharya, 2001). According to this definition, an organization should act in a way to "protect and advance the well-being of the community as a whole along with the benefit of the organization" (Davis \& Blomstrom, 1975, p. 5). Although some researchers confirmed the role of CSR policies in motivating employees (Skudiene \& Auruskeviciene, 2012), increasing organizational identification, organizational commitment, organizational citizenship behaviour and work meaningfulness (Bauman \& Skitka, 2012), there is still a lack of attention on the effects of perceived internal CSR and perceived external CSR activities separately on employees as a major internal stakeholder (Lee et al., 2013b), especially on employee engagement as a motivational construct (Bakker et al., 2007) and employees' identification with the organization (Collier \& Esteban, 2007). When the recent economic recession started in the 2000s, employee engagement has become an influential factor for organizational success in a competitive business world (Saks, 2006). Engaged employees exhibit pleasant behaviour towards their company like organizational commitment and a lower intention to leave the organization. Thus, considering the remarkable social changes in business world, it should be noted that identifying the determinants relevant to today's social activities which employee engagement is driven with seems to be essential. Furthermore, this study responds to the command for more studies on the individual-level effects of CSR (Aguilera et al., 2007; Rodrigo \& Arenas, 2008; Tziner et al., 2011; Van Buren III, 2005). Most of studies in CSR have been done in organizational level of analysis or focused on external stakeholders (Rego et al., 2011). The foundation of this study is grounded based on social exchange theory (Blau, 1964) and social identity theory (Tajfel \& Turner, 1979). Moreover, this study concentrates on the perception of employees towards CSR programs in their organisation. Accordingly, it can provide a clear insight to receive a better understanding of the effects of CSR on employees.

\section{Linkage between external and internal CSR and employee engagement}

According to Schaufeli et al. (2002b) work engagement is "a positive fulfilling, work-related state of mind that is characterized by vigor, dedication, and absorption" (p.74). "Vigor is characterized by high levels of energy and mental resilience while working, the willingness to invest effort in one's work, and persistence even in the face of difficulties. Dedication refers to being strongly involved in one's work and experiencing a sense of significance, enthusiasm, inspiration, pride, and challenge. Absorption, is characterized by being fully concentrated and happily engrossed in one's work, whereby time passes quickly and one has difficulties with 
detaching oneself from work" (p.74).

Based on the findings of Hewitt Associates (2010) research, CSR perception is one of the top five threats of employee engagement. Organizations should try to keep their present CSR commitment or risk a decrease in employee engagement (Kenexa Research Institute, 2007).

As outlined by stakeholder theory (Freeman, 1984), CSR initiatives provide beneficial consequences for organizations by fulfilling stakeholders' interests of the company, including employees, government, customer and shareholders (Lee et al., 2013a). This study perceives CSR as a multidimensional approach connected to various stakeholders of an organization that CSR has two main dimensions, internal and external (Amann \& Stachowicz-Stanusch, 2012; Brammer et al., 2007; Jamali et al., 2008). External CSR includes community and philanthropy contributions. By taking this approach, the company communicates with the physical environment and its ethical manner to consumers and other external stakeholders (Carroll, 1979). Companies concern all internal operations of company in internal CSR activities (Brammer et al., 2007).It is possible to justify the relation between external CSR and individuals' positive outcomes by the help of Social identity theory (SIT) which was originally presented by (Tajfel \& Turner, 1979). SIT declares that people tend to group themselves in social categories that impact their self-concept (Ashforth \& Mael, 1989; Greening \& Turban, 2000; Peterson, 2004). Based on SIT, employees receive a positive feeling of identity when their organization has a positive reputation (e.g. perhaps committing to CSR), and collaboration with a company that has a negative image in CSR could have a detrimental effect on employees' self-concept (Peterson, 2004). Prior researches have indicated a positive association of corporate prestige and its engagement in societal matters (Hess et al., 2002) and philanthropy (Brammer \& Millington, 2005). Thus, a positive relationship could be assumed between perceived external CSR activities and employee engagement.

Therefore, it can be hypothesized that:

Hypothesis 1: Perceived external CSR has a significant and positive effect on employee engagement.

In turn, there are some activities that company can conduct to enhance employee engagement and commitment in terms of working condition, giving equitable wages, appreciation and respect, communication, job security and personal and career development (Eweje \& Bentley, 2006). According to ISO 2600, these items are considered as internal CSR, because its concentration is on taking care of the employees in company (Santoso, 2014).

Social exchange theory (SET) emphasizes on social behaviour as the consequence of an exchange process (Blau, 1964). The exchange is related to a reciprocal behaviour (Konovsky $\&$ Pugh, 1994). Saks (2006) believes that a good and proper way through which workers can repay their companies is through their degree of engagement. When employees receive economic and socio-emotional supports from the organization, they reciprocate it by showing emotional, cognitive and physical behaviours to the company and their work role. So, when CSR activities satisfy employees' expectations, they are eager to repay with enthusiastic 


\section{Macrothink}

International Journal of Human Resource Studies

ISSN 2162-3058

2015, Vol. 5, No. 3

behaviour in terms of organizational citizenship behaviour, employee engagement, and other pleasant behaviours (Organ \& Lingl, 1995).

Therefore, it can be hypothesized that:

Hypothesis 2: Perceived internal CSR has a significant and positive effect on employee engagement.

\section{Mediating role of organizational identification between CSR and employee engagement}

The perception of oneness with the organization is named organizational identification (Ashforth \& Mael, 1989). When individuals identify themselves with the organization, they are more willing to behave in line with the interests of the company (Van Knippenberg \& Sleebos, 2006). SIT signifies that the CSR activities of company have a significant and direct impact on employees' organizational identification. Individuals attempt to attain or keep a positive social identity (Aberson et al., 2000), which they could obtain as a member of various groups (Ashforth \& Mael, 1989).

Thus, organizational identification derived from the image and the perceived prestige of the organization can be a driver of organizational identification (Dutton et al., 1994; Tyler \& Blader, 2002). In addition, corporate involvement in social issues and reputation are positively connected to each other (Hess et al., 2002).

According to SIT, employees tend to bolster their self-esteem and enhance their self-image by identifying with organizations and groups which are acknowledged for their responsibility and social engagement (Gond et al., 2010). On the other hand, CSR toward employees (internal CSR) consists of activities that guarantee the welfare and support of employees and good working conditions which can strengthen the employees' perception of self-respect and status in the company. CSR towards employees is related to employee's organizational identification. Indeed, individuals' judgment about the extent of respect from the company may impact the identification by improving the perceived status in their company (Tyler \& Blader, 2002). Consequently, employees who have high organizational identification tend to enhance their engagement in their work, because they believe this process is mutually beneficial (He \& Brown, 2013). In this regards, Employees perceive that external and internal CSR has a positive impact on organizational identification (Bhattacharya \& Korschun, 2008).

Therefore, it can be hypothesized that:

Hypothesis 3: Organizational identification mediates the relationship between perceived external CSR and employee engagement

Hypothesis 4: Organizational identification mediates the relationship between perceived internal CSR and employee engagement 


\section{Macrothink}

The conceptual model is presented in Figure 1.

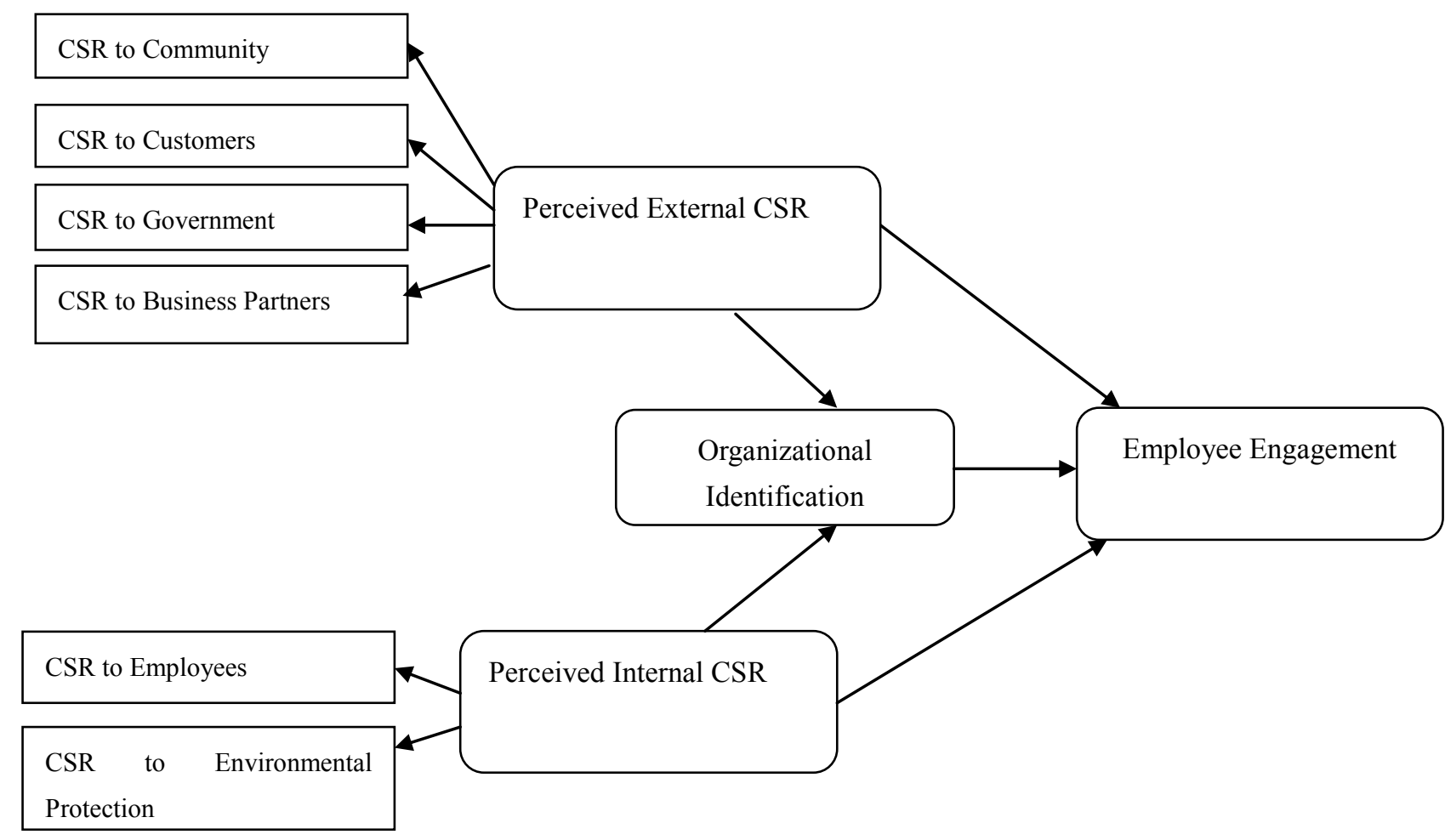

Figure 1: Conceptual Model

\section{Methodology}

This study focuses on all employees of four selected Iranian organizations which are located in Tehran. These companies are pioneers in carrying out CSR programs based on the report of CSR Centre in Iran and are involved in different CSR programs which publish CSR-related information on their websites. Data collected from employees as a unit of analysis because employees' reaction to CSR activities of their company is induced by their perception rather than using objective measurements (Brammer et al., 2007), predictors and outcomes need to be associated with regards to their source (Rupp et al., 2013). 1600 questionnaires distributed according to systematic random sampling by the help of researcher's friends who worked in those companies and 1100 questionnaire obtained (response rate: 68\%). The final sample comprised 1080 usable questioners.

\subsection{Measurements}

To measure perceived external CSR, we relied on perceptual measures and developed a scale of four sub-dimensions of employees' perception of external CSR. CSR to community measured by 6 items, CSR to business partners measured by 4 items, CSR to customer and CSR to governments measured by 2 items separately. Thus, the final instrument comprises of 14 items adapted from various sources (Lindgreen \& Swaen, 2010; Mijatovic \& Stokic, 2010; Mishra \& Suar, 2010; Skudiene \& Auruskeviciene, 2012; Turker, 2009). Perceived internal 


\section{Macrothink}

CSR as a second order construct is composed of two sub dimensions: CSR to employees measured by 10 items and CSR to environmental protection measured by 4 items. These 15 items were adapted from (Maignan \& Ferrell, 2000; Mishra \& Suar, 2010; Skudiene \& Auruskeviciene, 2012; Turker, 2009). Organizational identification was measured by 6-items adapted from (Ashforth \& Mael, 1989). Work engagement was measured with the shortened version of the Utrecht Work Engagement Scale (Schaufeli \& Bakker, 2004; Schaufeli et al., 2002a). Responses were measured on a five-point Likert scale ranging from 1 (Strongly Disagree) to 5 (Strongly Agree).

\section{Results and Analysis}

PLS-SEM method makes the researchers able to examine the reliability and validity of the construct measures (Hair et al., 2014, p. 96). For this purpose, first measurement model including convergent and discriminant validity and then structural model are estimated by PLS analysis as implemented in Smart PLS 2.0 (Hansmann \& Ringle, 2004). According to the approach of (Chin, 1998) and in order to find out the significance levels for loadings and path coefficients, the bootstrapping method has been employed. As both basic design and detailed design of model include higher-order constructs, a two-stage approach is followed to evaluate the structural model documented by (Hair et al., 2014).

In order to establish convergent validity which is defined as the degree to which multiple items are measuring the same concept are in agreement, we examined the factor loadings, composite reliability and average variance extracted (Hair et al., 2010). According to Chin et al. (2003), factor loadings should be at least 0.6 and preferably greater than 0.7. As shown in Table 1 all the items have factor loadings over 0.6 except for EMP4. This research accepted factor loadings of 0.6 and above as threshold in this study. In Table 1 composite reliability values ranged from 0.763 to 0.972 which is generally accepted at value of 0.7 or higher (Hair et al., 2010). The average variance extracted (AVE) should be greater than 0.50 (Barclay et al. 1995) and all construct measurements fulfilled this requirement (Table 1). In order to test the reliability, Cronbach's alpha values are above 0.6 as suggested by Nunnally and Bernstein (1994). Table 2 shows convergent validity of measurements. 


\section{Macrothink \\ International Journal of Human Resource Studies \\ ISSN 2162-3058 \\ 2015, Vol. 5, No. 3}

Table 1: Measurement Model

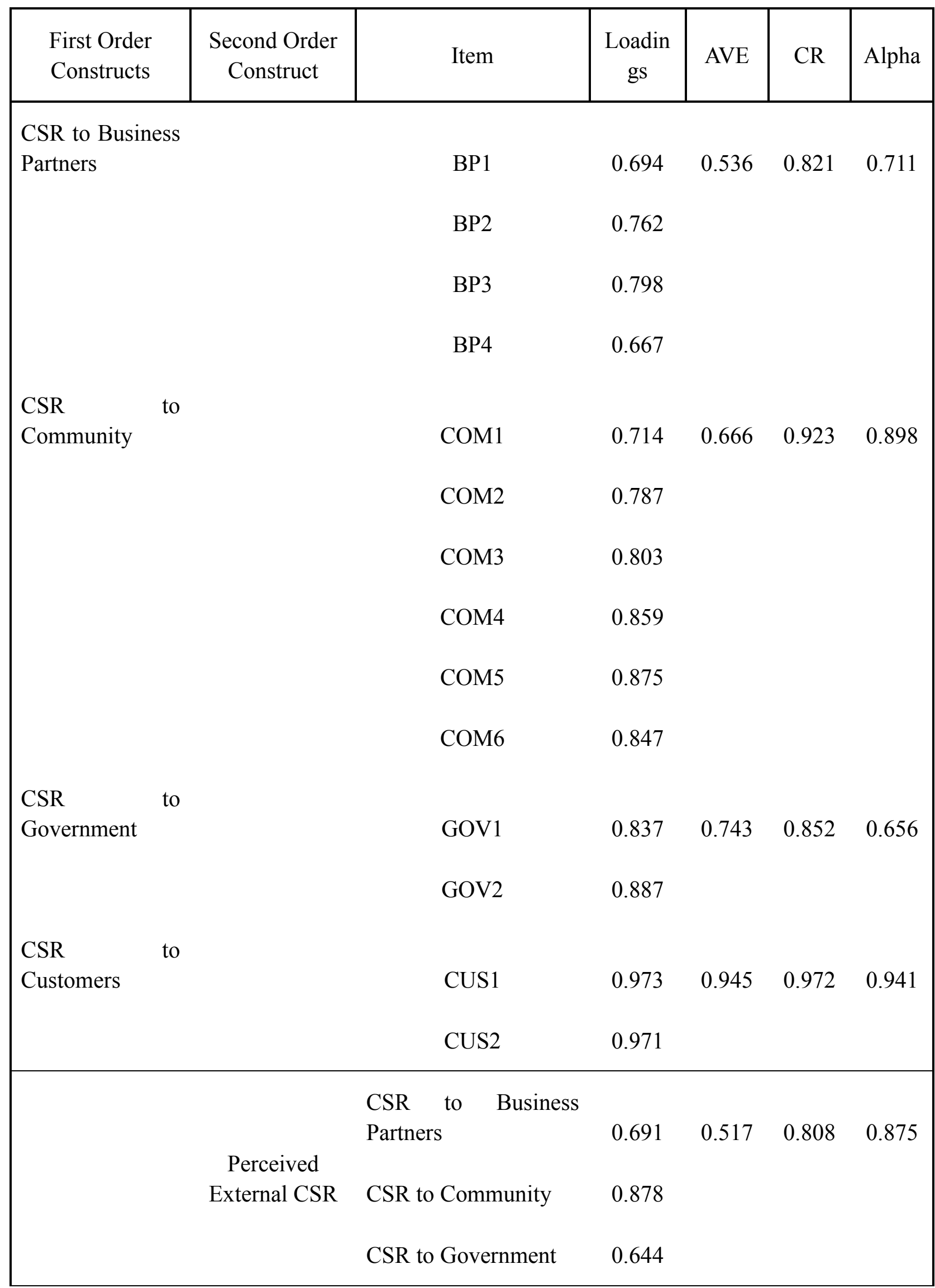




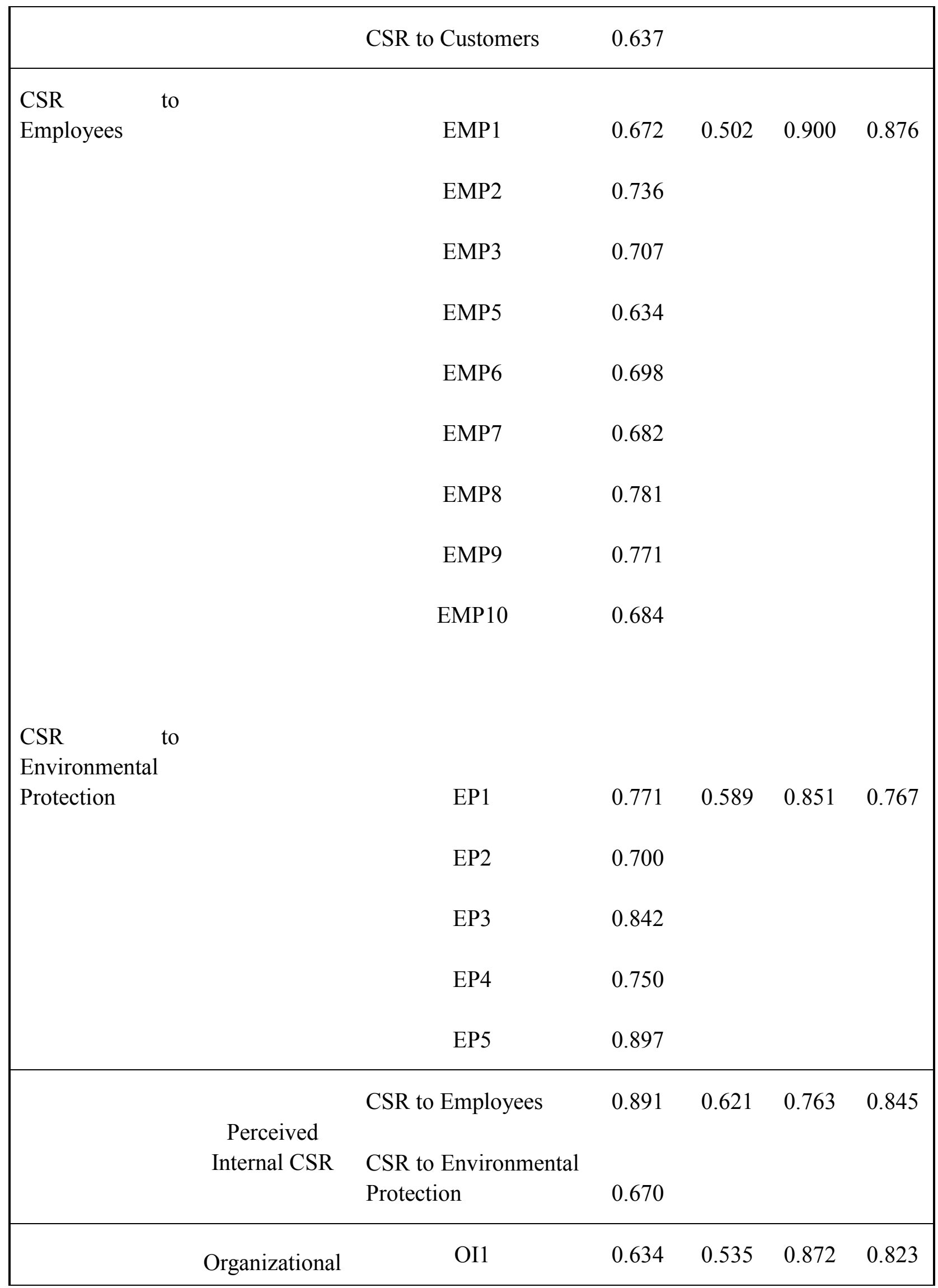




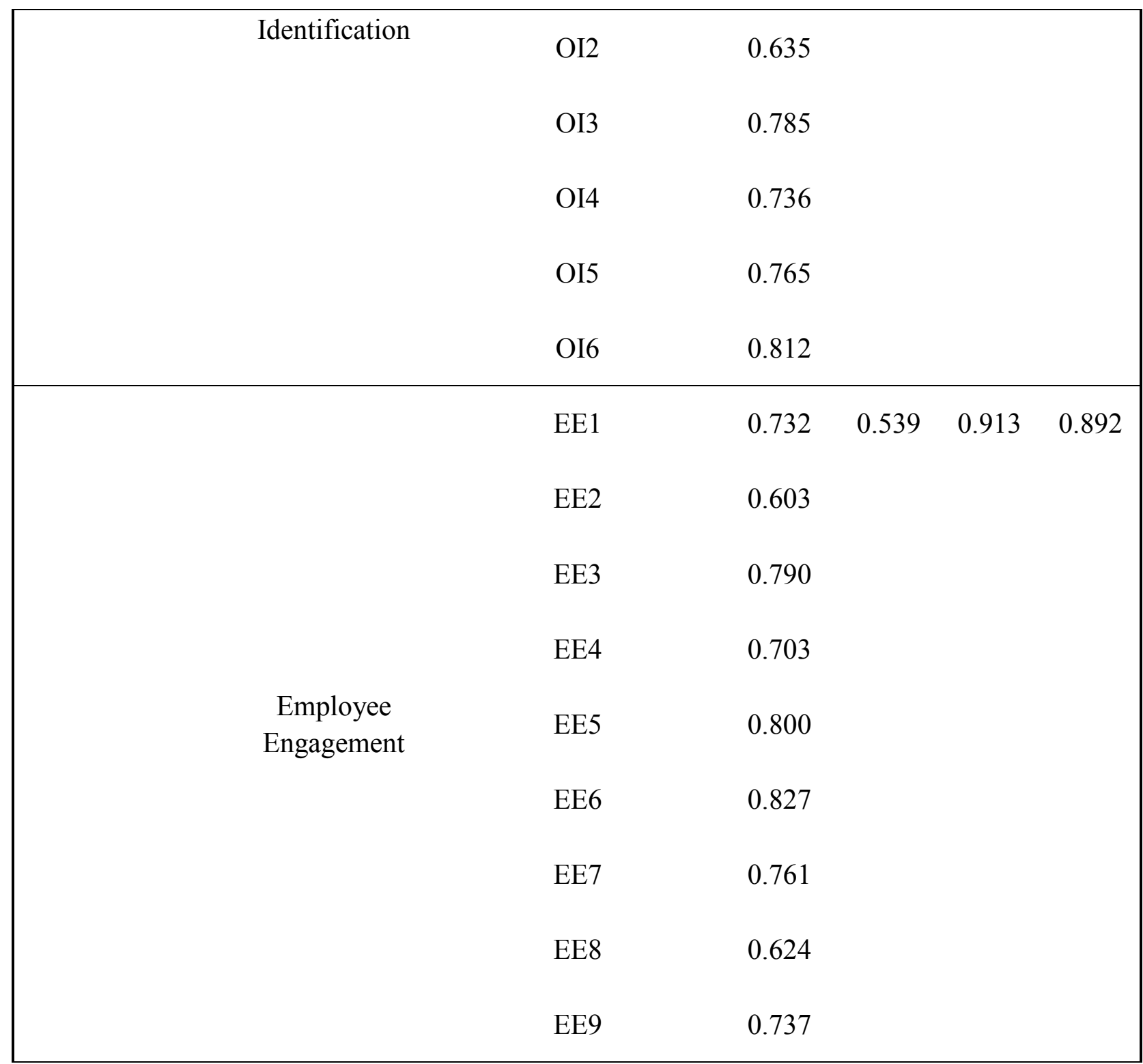

Note: $\mathrm{AVE}=$ Average Variance Extracted, $\mathrm{CR}=$ Composite Reliability

In the present research, the discriminant validity of the measurement model is evaluated through employing the criterion of (Fornell \& Larcker, 1981). In order to measure discriminant validity the correlation of a construct with its indicators (i.e. the square root of the AVE) should exceed the correlation between the construct and any other construct (Georges \& Eggert, 2003). In Table 2, all diagonal elements are greater than the non-diagonal elements in the corresponding rows and columns. Measurement model has been shown in Figure 1. 


\section{Macrothink}

International Journal of Human Resource Studies ISSN 2162-3058 2015, Vol. 5, No. 3

Table 2: Discriminant validity

\begin{tabular}{|c|c|c|c|c|c|}
\hline Constructs & $\begin{array}{l}\text { Employee } \\
\text { Engagement }\end{array}$ & $\begin{array}{l}\text { Organizational } \\
\text { Identification }\end{array}$ & $\begin{array}{l}\text { Perceived } \\
\text { External CSR }\end{array}$ & $\begin{array}{l}\text { Perceived } \\
\text { CSR }\end{array}$ & Internal \\
\hline \multicolumn{6}{|l|}{ Employee } \\
\hline Engagement & 0.734 & & & & \\
\hline Organizational & 0.662 & 0.730 & & & \\
\hline \multicolumn{6}{|c|}{ Perceived External } \\
\hline CSR & 0.632 & 0.524 & 0.719 & & \\
\hline \multicolumn{6}{|c|}{ Perceived Internal } \\
\hline CSR & 0.603 & 0.634 & 0.374 & 0.788 & \\
\hline
\end{tabular}

Note: Diagonals represent the square root of the AVE while the off-diagonals represent the correlations

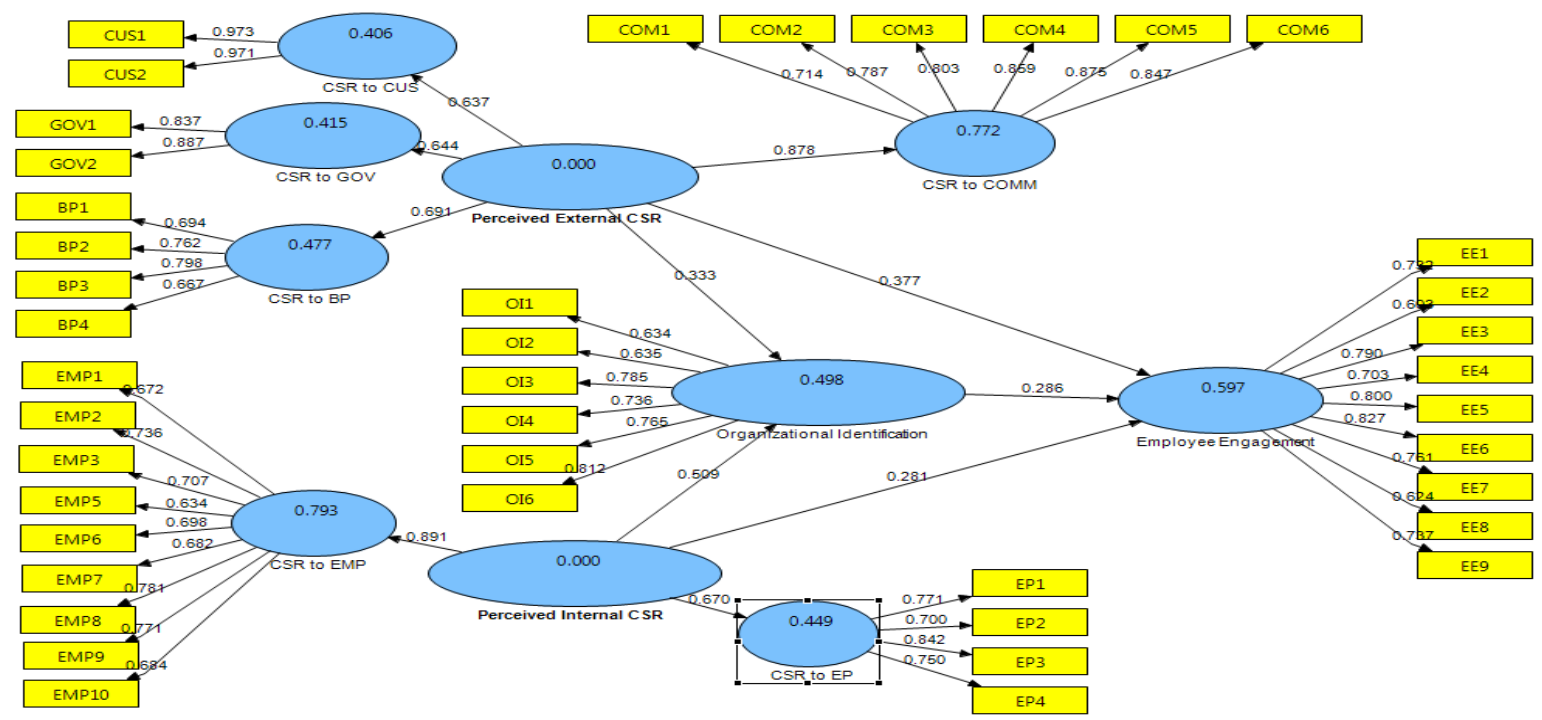

Figure 1: Measurement Model

\subsection{Assessment of the structural model}

The hypotheses were tested using Structural equation modelling method. We followed the two stage procedure recommended by (Hair Jr et al., 2014). As shown in Figure 2 and Table 3, 


\section{Macrothink}

International Journal of Human Resource Studies

ISSN 2162-3058 2015, Vol. 5, No. 3

hypotheses 1 and 2 were supported. Perceived External CSR $(\beta=0.386, p<0.01)$ has a positive effect on Employee Engagement. Perceived Internal CSR $(\beta=0.237, p<0.01)$ has a positive effect on Employee Engagement. Perceived External CSR has a greater effect on employee engagement, according to the greater path coefficient $(\beta=.386)$ and also with the medium effect size $\left(f^{2}=0.25\right)$, in compare to Perceived Internal CSR $(\beta=.237)$ with a small effect size on employee engagement $\left(f^{2}=0.09\right)$. To evaluate the structural models' predictive power, $\mathrm{R}^{2}$ indicates the amount of variance explained by the exogenous variables (Barclay et al., 1995). All three variables together explained 54.9\% of the variance in Employee Engagement. Perceived External and Internal CSR together explained $43.1 \%$ of the variance in Organizational Identification. Using a bootstrapping technique with a re-sampling of 1500 , the path estimates and t-statistics were calculated for the hypothesized relationships.

Table 3: Hypothesis results

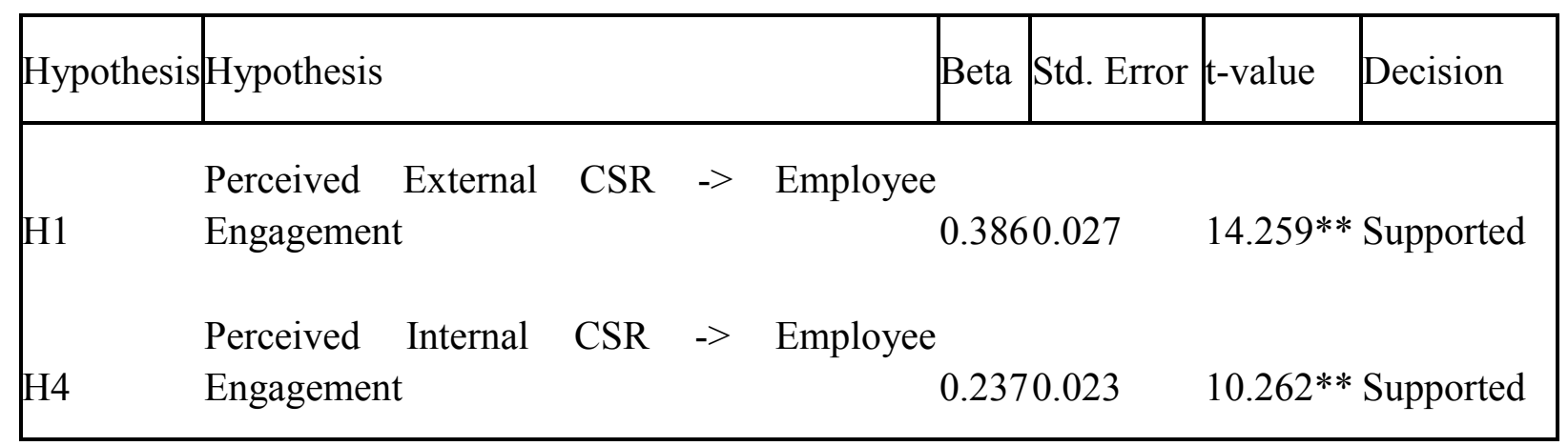

Note: ${ }^{* *} \mathrm{p}<0.01,{ }^{*} \mathrm{p}<0.05$

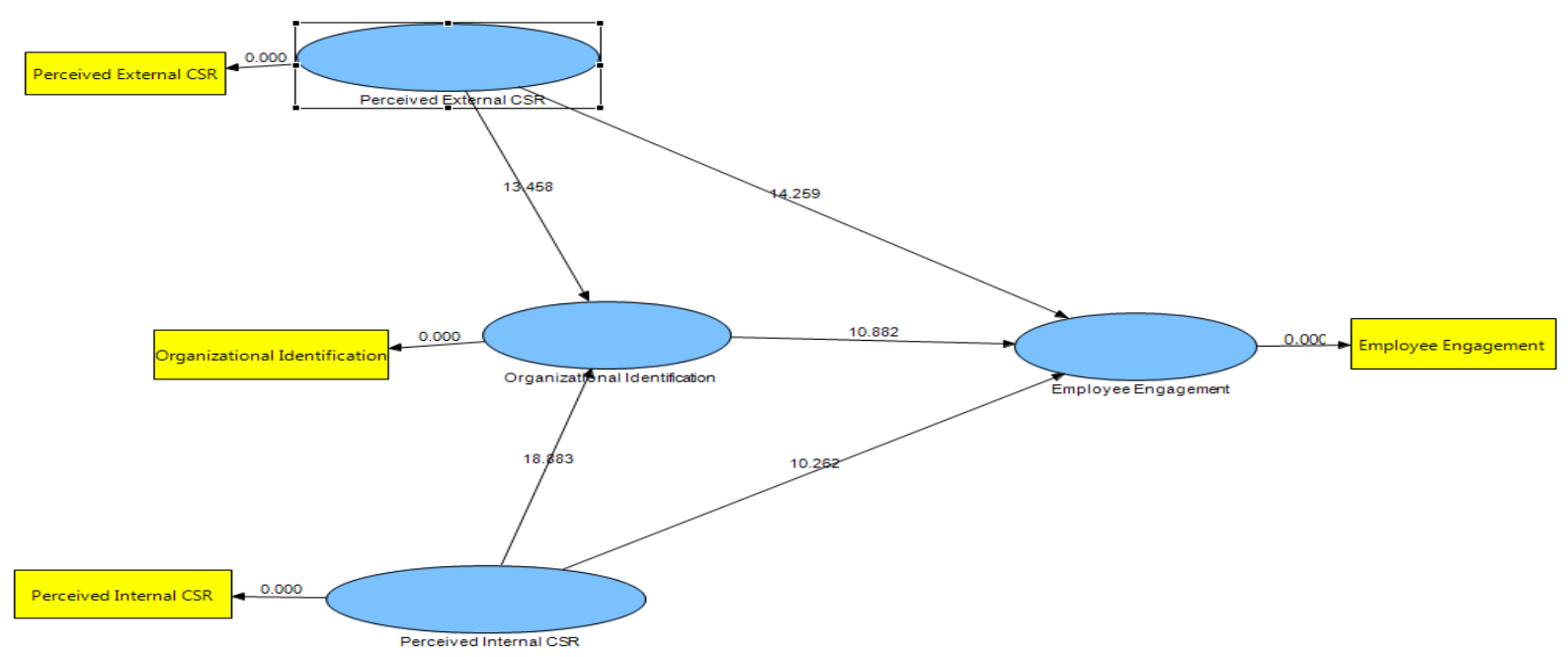

Figure 2: Structural model 


\subsection{The meditating effect of organizational identification}

Hypothesis 2 and 3 which were related to the mediating role of organizational identification were supported. The results are shown in Table 5.

$\mathrm{H}_{2}$ : Organizational Identification mediates the relationship between Perceived External CSR and Employee Engagement. (Supported)

The recent reviews propose to employ the bootstrapping approach of Preacher and Hayes (2008) in order to mediation analysis that is a non-parametric experiment and does not disrupt the assumption of the normality.

The bootstrapping analysis showed that the indirect effect $\beta=0.113(0.369 * 0.305)$ was significant with a t-value of 8.515. Also, as indicated by Preacher and Hayes (2008) the indirect effect $0.113,95 \%$ Boot $\mathrm{CI}$ : [LL $=0.087, \mathrm{UL}=0.138$ ] does not straddle a 0 in between indicating there is a mediation. Thus, we conclude that the mediation effect is statistically significant.

$\mathrm{H}_{3}$ : Organizational Identification mediates the relationship between Perceived Internal CSR and Employee Engagement. (Supported)

The bootstrapping analysis showed that the indirect effect $\beta=0.136(0.446 * 0.305)$ was significant with a t-value of 9.813. Also as indicated by Preacher and Hayes (2008), the indirect effect $0.136,95 \%$ Boot $\mathrm{CI}$ : [LL $=0.109$, $\mathrm{UL}=0.163$ ] does not straddle a 0 in between indicating there is a mediation. Thus, we can conclude that the mediation effect is statistically significant.

\section{Discussion}

This study contributes to the knowledge by advancing the understanding of employee perspectives regarding CSR activities. The results suggest that perceived external and internal CSR have a positive effect on employee engagement as well as confirms the mediating role of organizational identification in these relationships. This research originally proposed, and the results support, an identity-based motivation for employee engagement. Identity-based motivation has received increased attention in employee behaviour research (Ashforth et al., 2008; He \& Brown, 2013). This research incorporates organizational identification to explain effects different aspects of CSR (external and internal) on employee engagement. The current study indicates that employee's perception of CSR activities in organizations is crucial for enhancing both engagement and identification. According to the result external CSR has a greater effect on employee engagement than internal CSR which is in inconsistent with previous studies that indicated internal CSR has a greater effect on employee positive behaviour such as job satisfaction(De Roeck et al., 2014). Internal CSR directly addresses employees' needs and well-Beling (Cornelius et al., 2008), so, it is expected that it should have a greater effect on employee engagement. But is should be mentioned that in developing countries based on the high unemployment rate, job security is a vital factor in employees point of views. In developing countries such as Iran, companies' survival is not stable because of unstable economic issues. Iran ranks 130nd among 189 countries world-wide, and $13^{\text {th }}$ among 15 nations in the Middle East and North Africa in terms of ease of conducting 
trade and business (World Bank, 2014). Employees believe that external CSR activities guarantee the business survival in changeable circumstances. They think that the relationship between companies and the government will get stronger, if companies participate in community activities. In result, it indirectly affects the company's survival. The present research aims to explain the notion of external and internal CSR defined as second order construct, consisting of CSR to various stakeholders with the help of empirical data. This study opens new avenues for CSR-employee research. Furthermore, whereas organizational behaviour literature mainly focuses on leader-member exchange and other forms of direct exchange, we introduce the concept of indirect social exchange and suggest that employees reciprocate some of the benevolent actions of the organizations, even if those actions are not focused on them. The results would be useful for internal marketing. As employees' attitudes and behaviours constitute intangible resources that are valuable, rare, difficult to imitate, and lacking in perfect substitutes, CSR leads to intangible resources for the firms. Perceived external and internal CSR, identification significantly affect work- and job-related variable such as engagement which considered as a motivational factor and leads to less turnover intentions, which are important for competitive advantages

\section{References}

Aberson, C. L., Healy, M., \& Romero, V. (2000). Ingroup bias and self-esteem: A meta-analysis. Personality and Social Psychology Review, 4(2), 157-173.

Aguilera, R. V., Rupp, D. E., Williams, C. A., \& Ganapathi, J. (2007). Putting the S Back in Corporate Social Responsibility: A Multilevel Theory of Social Change in Organizations. Academy of Management Review, 32(3), 836-863.

Amann, W., \& Stachowicz-Stanusch, A. (2012). Integrity in organizations: building the foundations for humanistic management. London, UK: Palgrave Macmillan.

Ashforth, B. E., Harrison, S. H., \& Corley, K. G. (2008). Identification in organizations: An examination of four fundamental questions. Journal of Management, 34(3), 325-374.

Ashforth, B. E., \& Mael, F. (1989). Social identity theory and the organization. Academy of Management Review, 20-39.

Bakker, A. B., Hakanen, J. J., Demerouti, E., \& Xanthopoulou, D. (2007). Job resources boost work engagement, particularly when job demands are high. Journal of Educational Psychology, 99(2), 274.

Barclay, D., Higgins, C., \& Thompson, R. (1995). The partial least squares (PLS) approach to causal modeling: Personal computer adoption and use as an illustration. Technology Studies, 2(2), 285-309.

Bauman, C. W., \& Skitka, L. J. (2012). Corporate social responsibility as a source of employee satisfaction. Research in Organizational Behavior, 32, 63-86.

Bhattacharya, C. B., \& Korschun, D. (2008). Stakeholder marketing: Beyond the four Ps and the customer. Journal of Public Policy \& Marketing, 27(1), 113-116. 


\section{I Macrothink}

International Journal of Human Resource Studies ISSN 2162-3058 2015, Vol. 5, No. 3

Blau, P. M. (1964). Exchange and power in social life. New Brunswick, NJ: Transaction Publishers.

Brammer, S., \& Millington, A. (2005). Corporate reputation and philanthropy: An empirical analysis. Journal of Business Ethics, 61(1), 29-44.

Brammer, S., Millington, A., \& Rayton, B. (2007). The contribution of corporate social responsibility to organizational commitment. The International Journal of Human Resource Management, 18(10), 1701-1719.

Brown, T. J., \& Dacin, P. A. (1997). The company and the product: corporate associations and consumer product responses. The Journal of Marketing, 68-84.

Carroll, A. B. (1979). A three-dimensional conceptual model of corporate performance. Academy of Management Review, 4(4), 497-505.

Chin, W. W. (1998). Commentary: Issues and opinion on structural equation modeling. MIS Quarterly, 22(1), 7-16.

Chin, W. W., Marcolin, B. L., \& Newsted, P. R. (2003). A partial least squares latent variable modeling approach for measuring interaction effects: Results from a Monte Carlo simulation study and an electronic-mail emotion/adoption study. Information Systems Research, 14(2), 189-217.

Collier, J., \& Esteban, R. (2007). Corporate social responsibility and employee commitment. Business Ethics: A European Review, 16(1), 19-33.

Cornelius, N., Todres, M., Janjuha-Jivraj, S., Woods, A., \& Wallace, J. (2008). Corporate social responsibility and the social enterprise. Journal of Business Ethics, 81(2), 355-370.

De Roeck, K., Marique, G., Stinglhamber, F., \& Swaen, V. (2014). Understanding employees' responses to corporate social responsibility: mediating roles of overall justice and organisational identification. The international journal of human resource management, 25(1), 91-112.

Dutton, J. E., Dukerich, J. M., \& Harquail, C. V. (1994). Organizational images and member identification. Administrative Science Quarterly, 39(2), 239-263.

Eweje, G., \& Bentley, T. (2006). CSR and staff retention in New Zealand companies: a literature review.

Fornell, C., \& Larcker, D. F. (1981). Evaluating structural equation models with unobservable variables and measurement error. Journal of Marketing Research, 18(1), 39-50.

Freeman, R. E. (1984). Strategic management: A stakeholder approach. New York: Camberidge University Press.

Georges, L., \& Eggert, A. (2003). Key account managers' role within the value creation process of collaborative relationships. Journal of Business to Business Marketing, 10(4), $1-22$. 


\section{$\triangle$ Macrothink}

International Journal of Human Resource Studies ISSN 2162-3058

Gond, J.-P., El-Akremi, A., Igalens, J., \& Swaen, V. (2010). Corporate social responsibility influence on employees. ICCSR Research Paper Series. Nottingham University.

Greening, D. W., \& Turban, D. B. (2000). Corporate social performance as a competitive advantage in attracting a quality workforce. Business \& Society, 39(3), 254-280.

Hair, J., Black, W., Babin, B., \& Anderson, R. (2010). Multivariate Data Analysis: A Global Perspective. 2010. New Jersey: Prentice-Hall.

Hair, J. F., Hult, G. T. M., Ringle, C., \& Sarstedt, M. (2014). A primer on partial least squares structural equation modeling (PLS-SEM): Sage Publications.

Hair Jr, J. F., Hult, G. T. M., Ringle, C., \& Sarstedt, M. (2014). A primer on partial least squares structural equation modeling (PLS-SEM). US: SAGE Publications.

Hansmann, K.-W., \& Ringle, C. M. (2004). SmartPLS manual. University of Hamburg, Hamburg.

He, H., \& Brown, A. D. (2013). Organizational identity and organizational identification A review of the literature and suggestions for future research. Group \& Organization Management, 38(1), 3-35.

Hess, D., Rogovsky, N., \& Dunfee, T. W. (2002). The next wave of corporate community involvement: Corporate social initiatives. California Management Review, 44(2), 110-125.

Jamali, D., Safieddine, A. M., \& Rabbath, M. (2008). Corporate governance and corporate social responsibility synergies and interrelationships. Corporate Governance: An International Review, 16(5), 443-459.

Konovsky, M. A., \& Pugh, S. D. (1994). Citizenship behavior and social exchange. Academy of Management Journal, 37(3), 656-669.

Lee, C.-K., Song, H.-J., Lee, H.-M., Lee, S., \& Bernhard, B. J. (2013a). The impact of CSR on casino employees' organizational trust, job satisfaction, and customer orientation: An empirical examination of responsible gambling strategies. International Journal of Hospitality Management, 33, 406-415.

Lee, E. M., Park, S.-Y., \& Lee, H. J. (2013b). Employee perception of CSR activities: Its antecedents and consequences. Journal of Business Research, 66(10), 1716-1724.

Lindgreen, A., \& Swaen, V. (2010). Corporate social responsibility. International Journal of Management Reviews, 12(1), 1-7.

Maignan, I., \& Ferrell, O. (2000). Measuring corporate citizenship in two countries: The case of the United States and France. Journal of Business Ethics, 23(3), 283-297.

Mijatovic, I. S., \& Stokic, D. (2010). The influence of internal and external codes on CSR practice: The case of companies operating in Serbia. Journal of Business Ethics, 94(4), 533-552.

Mishra, S., \& Suar, D. (2010). Does corporate social responsibility influence firm 
performance of Indian companies? Journal of Business Ethics, 95(4), 571-601.

Nunnally, J. C., \& Bernstein, I. (1994). Psychological theory: New York: McGraw-Hill.

Organ, D. W., \& Lingl, A. (1995). Personality, satisfaction, and organizational citizenship behavior. The Journal of Social Psychology, 135(3), 339-350.

Peterson, D. K. (2004). The relationship between perceptions of corporate citizenship and organizational commitment. Business \& Society, 43(3), 296-319.

Preacher, K. J., \& Hayes, A. F. (2008). Assessing mediation in communication research. The Sage sourcebook of advanced data analysis methods for communication research. Thousand Oaks, CA: Sage, 13-54.

Rego, A., Leal, S., \& Pina e Cunha, M. (2011). Rethinking the Employees' Perceptions of Corporate Citizenship Dimensionalization. Journal of Business Ethics, 104(2), 207-218.

Rodrigo, P., \& Arenas, D. (2008). Do employees care about CSR programs? A typology of employees according to their attitudes. Journal of Business Ethics, 83(2), 265-283.

Rupp, D. E., Shao, R., Thornton, M. A., \& Skarlicki, D. P. (2013). Applicants' and Employees' Reactions to Corporate Social Responsibility: The Moderating Effects of First-Party Justice Perceptions and Moral Identity. Personnel Psychology, 66(4), 895-933.

Saks, A. M. (2006). Antecedents and consequences of employee engagement. Journal of Managerial Psychology, 21(7), 600-619.

Santoso, I. L. (2014). The Impact of Internal CSR towards Employee Engagement and Affective Commitment in XYZ Hotel Surabaya. iBuss Management, 2(2).

Schaufeli, W. B., \& Bakker, A. B. (2004). Job demands, job resources, and their relationship with burnout and engagement: A multi-sample study. Journal of Organizational Behavior, 25(3), 293-315.

Schaufeli, W. B., Martínez, I. M., Pinto, A. M., Salanova, M., \& Bakker, A. B. (2002a). Burnout and engagement in university students a cross-national study. Journal of Cross-Cultural Psychology, 33(5), 464-481.

Schaufeli, W. B., Salanova, M., González-Romá, V., \& Bakker, A. B. (2002b). The measurement of engagement and burnout: A two sample confirmatory factor analytic approach. Journal of Happiness studies, 3(1), 71-92.

Sen, S., \& Bhattacharya, C. B. (2001). Does doing good always lead to doing better? Consumer reactions to corporate social responsibility. Journal of Marketing Research, 38(2), 225-243.

Shen, J., \& Jiuhua Zhu, C. (2011). Effects of socially responsible human resource management on employee organizational commitment. The International Journal of Human Resource Management, 22(15), 3020-3035.

Skudiene, V., \& Auruskeviciene, V. (2012). The contribution of corporate social responsibility 


\section{Macrothink \\ International Journal of Human Resource Studies \\ ISSN 2162-3058 2015, Vol. 5, No. 3}

to internal employee motivation. Baltic Journal of Management, 7(1), 49-67.

Tajfel, H., \& Turner, J. C. (1979). An integrative theory of intergroup conflict. The social psychology of intergroup relations, 33(47), 74.

Turker, D. (2009). Measuring corporate social responsibility: A scale development study. Journal of Business Ethics, 85(4), 411-427.

Tyler, T. R., \& Blader, S. L. (2002). Autonomous vs. comparative status: Must we be better than others to feel good about ourselves? Organizational Behavior and Human Decision Processes, 89(1), 813-838.

Tziner, A., Oren, L., Bar, Y., \& Kadosh, G. (2011). Corporate Social Responsibility, Organizational Justice and Job Satisfaction: How do They Interrelate, If at All? . Revista de Psicología del Trabajo y de las Organizaciones, 27(1), 67-72.

Van Buren III, H. J. (2005). An employee-centered model of corporate social performance. Business Ethics Quarterly, 15(4), 687-709.

Van Knippenberg, D., \& Sleebos, E. (2006). Organizational identification versus organizational commitment: self-definition, social exchange, and job attitudes. Journal of Organizational Behavior, 27(5), 571-584.

World Bank (2014) retrieved from http://data.worldbank.org/indicator/IC.BUS.EASE.XQ (22 May 2015) 